\title{
Compressed Natural Gas Technology for Alternative Fuel Power Plants
}

\author{
Isworo Pujotomo ${ }^{1, *}$ \\ ${ }^{1}$ Electrical Engineering Department, School for Engineering of PLN's Foundation for Education \& Welfare PT. PLN (Persero) Jakarta, \\ Indonesia
}

\begin{abstract}
Gas has great potential to be converted into electrical energy. Indonesia has natural gas reserves up to 50 years in the future, but the optimization of the gas to be converted into electricity is low and unable to compete with coal. Gas is converted into electricity has low electrical efficiency (25\%), and the raw materials are more expensive than coal. Steam from a lot of wasted gas turbine, thus the need for utilizing exhaust gas results from gas turbine units. Combined cycle technology (Gas and Steam Power Plant) be a solution to improve the efficiency of electricity. Among other Thermal Units, Steam Power Plant (Combined Cycle Power Plant) has a high electrical efficiency (45\%). Weakness of the current Gas and Steam Power Plant peak burden still using fuel oil. Compressed Natural Gas (CNG) Technology may be used to accommodate the gas with little land use. CNG gas stored in the circumstances of great pressure up to $250 \mathrm{bar}$, in contrast to gas directly converted into electricity in a power plant only 27 bar pressure. Stored in CNG gas used as a fuel to replace load bearing peak. Lawyer System on CNG conversion as well as the power plant is generally only used compressed gas with greater pressure and a bit of land.
\end{abstract}

\section{Introduction}

Electricity consumption per capita is an index of living standard of a country. In Indonesia, with the increasing industrial activity and population, the need for electrical power also increased. Due to the increase in fuel prices today's world, PT. PLN (Persero) as one of the state electricity company should think businesses operating cost savings, of which $75 \%$ are in fuel costs. One effort that can be taken by PT. PLN (Persero) is the main power plant fuel switching from fuel oil (HSD and MFO) into natural gas.[1] [2]

Basically PLN operate Power Gas and Steam (Power Plant) as peaker plants (peak load) because operating costs are more expensive than base load generation (base load). Oil energy crisis that resulted in soaring oil prices caused the gas to be used as an alternative PLN for plant outside of peak load. During this time, when the load is low (outside of peak load), the supply of gas for the power plant is not absorbed optimally, as appropriate loading pattern in the Java-Bali system more filled by many ordinary coal plant production is cheaper. Nevertheless, the unabsorbed gas must still be paid, the gas supply contract is a take or pay. While at peak load gas supply is insufficient, so that some plants have to be operated using the fuel.[2]

Presence technology Compressed Natural Gas (CNG) is expected to be a solution to the problem mentioned above. Gas supply flow rate remain while outside of peak load, partially compressed into $\mathrm{CNG}$ tube pressurized to 250 bar for 10 hours. CNG use of technology for the generation of a rock thing, not in other countries. Much of the world uses Liquid Natural Gas (LNG) technology.

\section{Gas Power Plant and Steam}

Power Plant is a combination of the working principle of the power plant by gas and steam power plant or socalled combined cycle. Power plant using a gas turbine unit driving the generator, so that the working principle of the power plant following the working principle of the gas turbine. The gas turbine is designed and made for converting heat energy from burning fuel into mechanical energy. The system uses the principle of the Brayton cycle gas power plant. While the working principle of the power plant is converting the chemical energy in the fuel is converted into thermal energy in the form of vapor pressure and high temperature, the steam then changed to mechanical energy to drive generator. The system uses the principle of the Rankine cycle power plant. Figure 1 is a Grati power plant in East Java with a capacity of $526.850 \mathrm{MW}$ which use the principle of combined cycle.[1] [3]

\footnotetext{
Corresponding author: isworop $@$ yahoo.com
} 


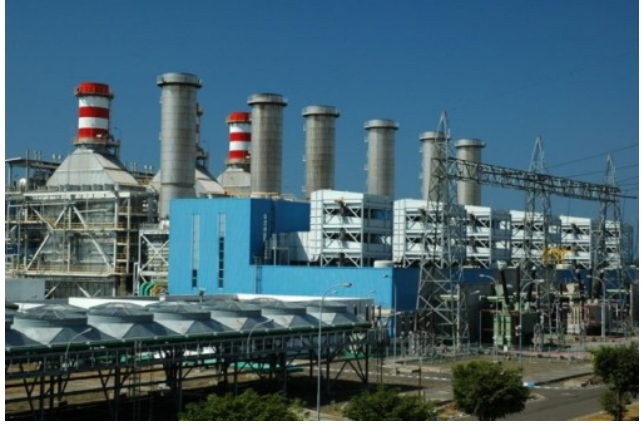

Fig. 1. Grati Power Plant in East Java (Pasuruan)

Grati Power Plant in East Java (Pasuruan) consists of: Gas Turbine: 112.450 MW x 3; Steam turbine: 189.500 MW; Block output 526.850 MW.

\subsection{Combined cycle}

In improving the efficiency of gas turbines do combined cycle gas turbine with a steam turbine cycle in order to obtain the combined cycle which is commonly referred to as "co-generation". Meanwhile, to improve the thermal efficiency of the gas turbine is used combined cycle, forming a so-called "Combined Cycle" or Steam Gas Power Plant (Power Plant). Cycle power plant applying the Brayton cycle, whereas the ideal cycle Rankine cycle power plant apply.

\subsection{Brayton cycle;}

Brayton cycle (Brayton Cycle) shown in Figure 2 consists of isentropic compression process that ended with the release of heat at constant pressure. In Bryton cycle of each state processes can be analyzed as follows:[4]

1-2 (isentropic Compression).

Work required by the compressor:

2-3: Entry of the fuel at a constant pressure.

3-4: isentropic expansion in the turbine.

4-1: Discharge heat at constant pressure into the air.
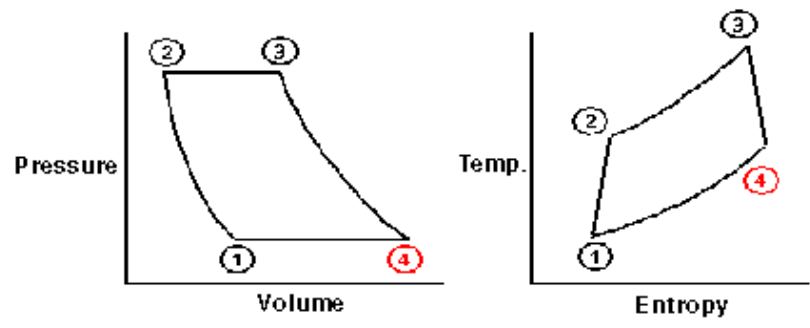

Fig. 2. $p$-v and t-s Brayton Syklus Diagram [3]

From Figure 2 on $\mathrm{p}-\mathrm{v}$ diagram and $\mathrm{t}-\mathrm{s}$, it can be seen that the inclusion of heat takes place at a constant pressure:

$\mathrm{Q}_{\mathrm{in}}=\mathrm{m} \cdot \mathrm{c}_{\mathrm{p}} \cdot\left(\mathrm{T}_{3}-\mathrm{T}_{2}\right)$

- Spending too hot at constant pressure:

$\mathrm{Q}_{\text {out }}=\mathrm{m} \cdot \mathrm{c}_{\mathrm{p}} \cdot\left(\mathrm{T}_{4}-\mathrm{T}_{1}\right)$

- Thus, useful work can be formulated as follows:
$\mathrm{W}_{\mathrm{u}}=\mathrm{Q}_{\text {in }}-\mathrm{Q}_{\mathrm{ou}}$

c. Rankine cycle;

Rankine cycle in Figure 3 is used in the steam turbine power plant system. The sequence steps as follows:

$\mathrm{a}-\mathrm{b}$ : Water is pumped from the pressure $\mathrm{p} 2$ be $\mathrm{p} 1$. This step is a compression step isentropis, and this process occurs at the water pump filler.

b - c: Air pressure is increased the temperature until it reaches boiling point. Occurred in the LP heater, HP heater and Economizer.

c - d: Water transformed into saturated steam. This step is called evaporation with isobars isothermis process, occurred in the boiler is in the wall tube (riser) and the steam drum.

$\mathrm{d}$ - e: Steam is heated further until the vapor reaches a temperature further work into hot steam (superheated vapor). The move occurred in the boiler superheater with the isobars.

e - f: Steam does work so that the pressure and the temperature dropped. This step is a step isentropis expansion, and occur within the turbine.

f - a: Disposal of latent heat of the steam that turns into condensate water. This step is isothermis isobars, and occurs in the condenser.

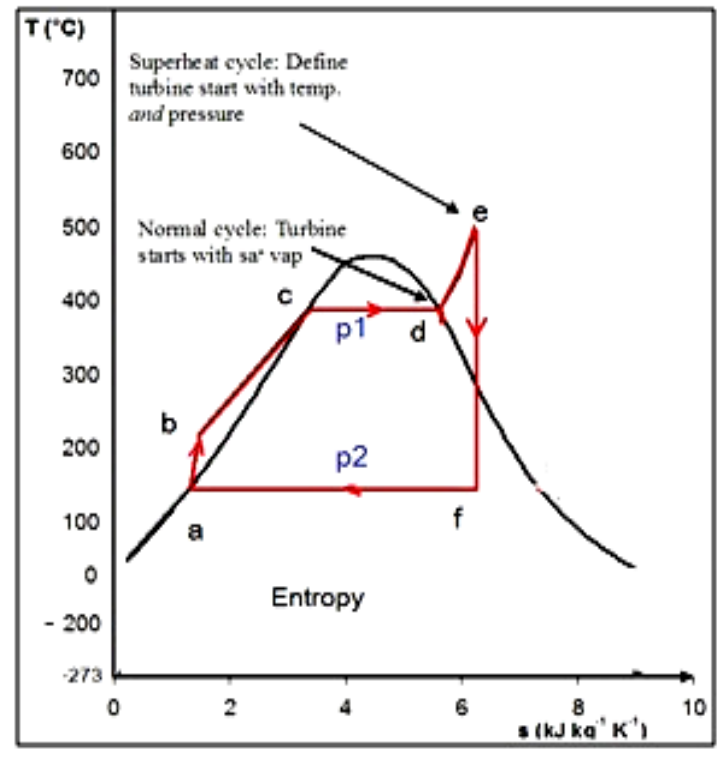

Fig. 3 Diagram T - s Rankine Cycle [5][4]

\section{Compressed natural gas}

Compressed Natural Gas (CNG) is a fluid gas that has been processed into a high-pressure natural gas compression in a tube. In general, the major components containing $\mathrm{CNG}$ methane $\left(\mathrm{CH}_{3}\right)$ and ethane $\left(\mathrm{C}_{2} \mathrm{H}_{8}\right)$ with fraction of about $90 \%$. CNG is made by compressing methane $\left(\mathrm{CH}_{4}\right)$, which is extracted from natural gas. $\mathrm{CNG}$ is stored and distributed through the packaging in the tank (pressure vessel or pressure vessel). Ideally, the pressure on the gas pipeline is 11 bar, while the CNG requires a pressure of $200 \mathrm{bar}$, or $197 \mathrm{~atm}, 197$ times normal air pressure. With a pressure of 200 bar, charging the equivalent of 130 liters of premium gas can be done 
within 3-4 minutes. Figure 4 shows an example of $\mathrm{CNG}$ tubes.[6] [7]

Calorific value is the amount of heat generated by the combustion of materials or fuels. Measured in units of energy per amount of material, for example $\mathrm{kJ} / \mathrm{kg}$. Calorific value of the fuel is divided into two kinds, namely: a calorific value above (HHV) and lower calorific value (LHV).

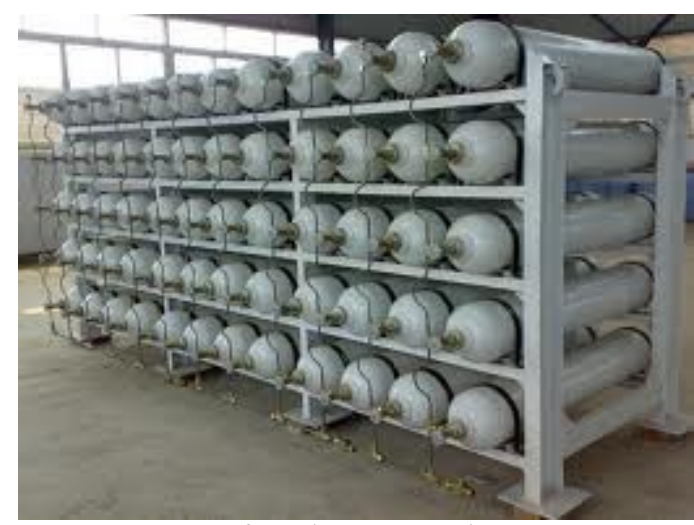

Fig. 4. pressure of 200 bar CNG Tubes

Higher Heating Value (HHV) or above is the calorific value calorific value derived from the combustion of $1 \mathrm{~kg}$ of fuel, taking into account the vapor condensation heat (water resulting from combustion are in liquid form). HHV gas $=1089 \mathrm{Btu} / \mathrm{ft} 3=52.225 \mathrm{MJ} /$ $\mathrm{kg}$.

Lower Heating Value (LHV) or lower calorific value is obtained calorific value of combustion heat regardless vapor condensation (water produced from burning was on gas / steam). LHV gas $=983 \mathrm{Btu} / \mathrm{ft}^{3}=47.141 \mathrm{MJ} /$ $\mathrm{kg}$.

A fuel flash point is the lowest temperature at which the fuel can be heated so that steam output flame briefly when passed a flame. Flash point $-187.80 \mathrm{C}$ CNG temperature. Burning point is the lowest temperature at which sufficient oxygen conditions, spontaneous combustion can occur. Burning point unit is degrees $\left({ }^{0}\right)$ or degrees Celsius $\left({ }^{0}\right)$ Fahrenheit. CNG point at a temperature of $540^{\circ} \mathrm{C}$. Octane number is a number that shows the number as a percentage (\%) volume of isooctane in a mixture that consists of n-heptane issoctane and that does not cause outbreaks in the fuels being tested in a compression chamber of a combustion chamber.[8] [9]

According to the science of thermodynamics, the higher the ratio / percentage of compression used, the higher the efficiency of combustion in the combustion chamber. CNG octane value of the percentage of $130 \%$.

Tube specifications for CNG fuel is as follows:[8]

Capacity $=50-100\left(\mathrm{~m}^{3}\right)$

Dimensions $=11657 \times 2428 \times 3028$

Massa Netto $\quad=10760 \mathrm{~kg}$

Nominal Diameter $=$ DN80

Material $=16 \mathrm{MNR}$

The selected specification is commercial fleet refuel CNG compressor station, with a pressure of 1.4-250 bar and a capacity of $1.3 \mathrm{~m}^{3} / \mathrm{h}$.

\section{Output Power Cng Capacity Analysis}

\subsection{Technical Analysis}

Grati power plant that has the capacity of 3.5 MMSCF $\mathrm{CNG}$ with gas turbine efficiency of $45 \%$ and $\mathrm{CF}=0.8$ / year in operation for 6 hours output power can be determined as follows:

Production $\mathrm{MWh}=(\mathrm{SCF} \times 922 \times \eta) / 3413$

$$
\begin{aligned}
3413 & =(3.5 \times 1,000,000 \times 922 \times 0.45) / \\
& =425.476 \mathrm{MWh} \\
\text { Output power } & =(\text { Production MWh }) /(\text { operating time }) \\
=(425.476 \mathrm{MWh}) /(6 \mathrm{~h}) & =70.91 \mathrm{MW}
\end{aligned}
$$

Fuel is needed to generate power output of $70.91 \mathrm{MW}$ are as follows:

$$
\begin{aligned}
\mathrm{BBG}= & (3413 \times \text { Power Output }) / \eta \\
& =(3413 \times 70.91) / 0.45 \\
& =538 \mathrm{MMBTU} \\
& =512,380.9524 \mathrm{ft} 3 \\
& =14,508,579.05 \mathrm{lt}
\end{aligned}
$$

with:

$1 \mathrm{ft}^{3}=1050 \mathrm{btu}$

$1 \mathrm{ft}^{3}=28.316 \mathrm{lt}=28.316 \mathrm{dm}^{3}$

\subsection{Economical analysis [6]}

\subsubsection{Fixed costs}

According to the above matter at Grati power plant installed two units of CNG with a capacity of $2 \times 70.91$ MW. If the interest rate i of $12 \%$ by age 25 years plants can be seen:

$\mathrm{CRF}=\left(\mathrm{i}(1+\mathrm{i})^{\mathrm{n}}\right) /\left((1+\mathrm{i})^{\mathrm{n}-1}\right)=\left(0.12(1+0.12)^{25}\right) /((1+$ $\left.0,12)^{25-1}\right)=0.127$

Development costs PLT-CNG $=5.94864 \$ / \mathrm{kWh}$

$\mathrm{CF}=80 \%$

$\mathrm{CC}=$ (cost of construction of generating capacity $\mathrm{x}$ CRF) / W

$=\left(5.94864 \times 400 \times 10^{3} \times 0.127\right) /\left(400 \times 10^{3} \times 0.8 \times 6 \times\right.$ $365)$

$=4.4 \times 10^{-4} \$ / \mathrm{kWh}$

\subsubsection{Operating and maintenance costs}

$\mathrm{O} \& \mathrm{M}=($ total cost of $\mathrm{O} \& \mathrm{M}) /(\mathrm{CF} \times$ time $\mathrm{x}$ cap $)=$ $(20347106.98(\$)) /\left(0.8 \times 6 \times 365 \times 400 \times 10^{3}(\mathrm{kWh})\right)=$ $0.03 \$ / \mathrm{kWh}$

\subsubsection{The cost of fuel}

$\mathrm{Fc}=(\mathrm{Ui} 860) / 0.45=\left(860 \times 7.313 \times 10^{(-7)}\right) / 0.45=1.4$ $\mathrm{x} 10^{-3} \$ / \mathrm{kWh}$

\subsubsection{Total cost}

$\mathrm{Tc}=\mathrm{CC}+\mathrm{O} \& \mathrm{M}+\mathrm{Fc}=4.4 \times 10-41.4 \times 10-3+0.03=$ $0.03184 \$ / \mathrm{kWh}$ 


\section{Conclusion}

From the analysis of the utilization of CNG fuel at Grati power plant can be concluded that:

1. The use of CNG is useful to reduce system losses on gas purchases at gas power plant (power plant) in take or pay that lead to wasted unused gas.

2. Costs required by $\mathrm{CNG}$ stations is equal to $0.03184 \$$ / $\mathrm{kWh}$ with details:

a) Construction of $4.4 \times 10^{-4}$ Cost $\$ / \mathrm{kWh}$

b) Operation and Maintenance Costs $\$ 0.03 / \mathrm{kWh}$

c) Cost of Fuel $1.4 \times 10^{-3} \$ / \mathrm{kWh}$

CNG has a lower density than air, so it is not flammable.

\section{References}

1. Ahmad, A.. Meningkatkan Efisiensi Steam Turbine ketika Menggunakan Bahan Bakar Minyak. Pasuruan : PLTGU Grati, (2011)

2. Mohamad, S. Pengoperasian Preheater Dalam Mengoptimalkan Pemakaian Air Kondensat. Pasuruan : PLTGU Grati, (2015).

3. Bo Yan Xu, Mikio Furuyama., JSAE Review 18, 57-82, (1997)
4. Mikio Furuyama, Bo Yan Xu. Mixing Flow Phenomena of Natural Gas and Air in the Mixer of a CNG Vehicle. SAE 981391. Chiba University. Japan, (1998).

5. Heywood, J.B., Internal Combustion Engine Fundamental, McGraw-Hill, Singapore, (1988)

6. K. Kadirgama, M. M. Noor, A. R. N. A. Rahim, R. Devarajan, M. R. M. Rejab, N. M. Zuki N. M, Design and Simulate Mixing of a Compressed Natural Gas With an Air Mixing Device, MUCET (2008).

7. S. Shiga, S. Ozone, H.T.C. Machacon, T. Karasawa, H. Nakamura., A Study of the Combustion and Emission Characteristic of Compresed Natural Gas Direct Injection Stratified Combustion Using a Rapid Compression Machine, Combustion Institute Gunma University, Japan, (2002)

8. Pulkrabek, W.W., Engineering Fundamentals of The Internal Combustion Engines, 2nd Edition, Pearson Prentice-Hall, Wisconsin. (2004)

9. Willard. W. Pulkrabek, Enginering Fundamental of the Internal Combustion Engine, Prentice Hall, Upper Sadle River, New Jersey, (2003) 